\title{
Quantitative Traits Analysis in Rice (Oryza sativa L.) Genotypes
}

\author{
B. Manjunatha*, B. Niranjanja Kumara, A.M. Maruthesha and H.G. Sannathimmappa \\ Seed Unit, Agricultural and Horticultural Research Station, Kathalagere, University of \\ Agricultural and Horticultural Sciences, Shivamogga, Karnataka, India \\ *Corresponding author
}

\section{A B S T R A C T}

Keywords

Rice, Variability, Correlation

Article Info

Accepted:

30 October 2019

Available Online:

10 November 2019
The present study consists of sixty four rice genotypes that were evaluated at Agricultural and Horticultural Research station, Ponnampet. Karnataka to study genetic variability, heritability and genetic advance for grain yield and four yield associated traits. The experiment was conducted using $6 \times 6$ simple lattice design with two replications during the 2014 kharif main cropping season. The analysis of variance revealed statistically significant differences $(p<0.05)$ indicating the existence of genetic variability among the 64 genotypes for all the traits studied. Significant differences were observed for grain yield that ranged from 1662.00 to $6414.00 \mathrm{~kg} / \mathrm{ha}$ with overall mean value of $4522.00 \mathrm{~kg} / \mathrm{ha}$ Higher PCV and GCV values were exhibited by yield $\mathrm{kg} / \mathrm{ha}$ which suggests the possibility of improving this trait through selection. The highest heritability was recorded for panicles per square metre followed by plant height, yield $\mathrm{kg} / \mathrm{ha}$ and Days to fifty per cent flowering. High to medium heritability coupled with high GCV and high genetic advance as percentage of means were exhibited for plant height, panicles per square metre. High genetic advances as percent of means were recorded by yield $\mathrm{kg}$ per hectare, panicles per square metre, Plant height $(\mathrm{cm})$ and days to fifty per cent flowering.

\section{Introduction}

Rice is a self-pollinated cereal crop belonging to the family Gramineae (synonym-Poaceae) under the order Cyperales and class Monocotyledon having chromosome number $2 \mathrm{n}=24$ (1). The genus Oryza includes a total of 25 recognized species out of which 23 are wild species and two, Oryza sativa and Oryza glaberrima are cultivated (2). It can survive as a perennial crop and can produce a ratoon crop for up to 30 years but cultivated as annual crop and grown in tropical and temperate countries over a wide range of soil and climatic condition. Rice and agriculture are still fundamental to the economic development of most of the Asian countries. In much of Asia, rice plays a central role in politics, society and culture, directly or indirectly employs more people than any other sector. A healthy rice industry, especially in Asia's poorer countries, is crucial to the 
livelihoods of rice producers and consumers alike. Farmers need to achieve good yields without harming the environment so that they can make a good living while providing the rice-eating people with a high-quality, affordable staple. Underpinning this, a strong rice research sector can help to reduce costs, improve production and ensure environmental sustainability. Indeed, rice research has been a key to productivity and livelihood.

Rice is the second largest produce cereal in the world in 158.3million hectare area with annual production of about 685.24 million metric tons and also the staple food for over one third of the world's population and more than $90 \%$ to $95 \%$ of rice is produced and consumed is Asia. Rice (Oryza sativa L.) is the staple food in India and grown in a wide range of environments ranging from the upland areas like Chittagong Hill Tracts, Sylhet and Garo Hills, with little moisture, to situations where the water is 3-4 meter deep. Bangladesh is ranked as fourth in rice production with annual production of 47.72 million metric ton in the world. Bangladesh has Rice is the most consumed cereal grain in the world. It is staple food crop for more than half of the world's human population.

Yield enhancement is the major breeding objective in rice breeding programmes and knowledge on the nature and magnitude of the genetic variation governing the inheritance of quantitative characters like yield and its components is essential for effective genetic improvement. A critical analysis of the genetic variability parameters, namely, Genotypic Coefficient of Variability (GCV), Phenotypic Coefficient of Variability (PCV), heritability and genetic advance for different traits of economic importance is a major pre-requisite for any plant breeder to work with crop improvement programs. Further, information on correlation coefficients between grain yield and its component characters is essential for yield improvement, since grain yield in rice is a complex entity and is highly influenced by several component characters. Studies on path co-efficient also provide useful information regarding the direct and indirect effects of different yield component characters on grain yield and thus aid in the identification of effective selection criteria for effective yield improvement.

The present investigation was undertaken in this context to elucidate information on variability, heritability, genetic advance, character associations and path of effect in promising rice genotypes. A good knowledge of genetic resources might also help in identifying desirable genotypes for future hybridization program.

\section{Materials and Methods}

The experiment was carried out during kharif, 2014 at Agricultural and Horticultural Research Station, Ponnampet. The material comprised of 64 elite initial varietal traillate varieties sown in a simple lattice design with two replications with spacing of $20 \times 15 \mathrm{~cm}$.

Data were recorded on five randomly selected plants in each entry in each replication for the traits days to $50 \%$ flowering, Plant height $(\mathrm{cm})$, number of panicles per square metre, except yield which recorded in $\mathrm{kg} / \mathrm{plot}$ converted into $\mathrm{kg} / \mathrm{ha}$.

The data subjected to INDOSTAT software to estimate Genetic coefficient of variation (\%), phenotypic coefficient of variation (\%), Heritability (\%) (Broad sense), Genetic Advance and Genetic Advance as percent of mean. The estimates for variability treated as per the categorization proposed by Siva Subramanian and Madhavamenon (4), heritability and genetic advance as percent of mean estimates according to criteria proposed by Johnson et al., (2). 


\section{Results and Discussion}

In the present study analysis of variance revealed the existence of significant differences among genotypes for all traits studied. The mean, variability estimates i.e., Genetic coefficient of variation (\%), phenotypic coefficient of variation (\%), Heritability (\%) (Broad sense), Genetic Advance as percent of mean are presented in Table 1. All traits under studied have higher phenotypic coefficient of variation than genotypic coefficient of variation. The magnitude of phenotypic coefficient of variation and genotypic coefficient of variation was moderate to high for the traits panicles per square metre and yield $(3,5)$. The high PCV observed for yield per hectare (5).

The high GCV obtained for number of panicles per square metre indicating the improvement is possible through selection. Genotypic coefficient of variation measures the extent of genetic variability percent for a trait but does not assess the amount of genetic variation which is heritable. Heritability estimates were high for all the characters. The heritability estimates along with genetic advance can be useful to predict effect of selection in selection programmes.

The traits like days to fifty percent flowering, yield (7) and plant height exhibited high magnitude of genetic advance as percent of mean. The traits plant height, days to fifty percent flowering, panicles per square metre and yield have high heritability along with genetic advance as percent of mean indicate that these characters attributable to additive gene effects which are fixable revealing that improvement in these characters would be possible through direct selection.

Sixty four rice genotypes along with one standard checks were evaluated for four yield and yield attributing traits. Results of the present investigation on variability, heritability and genetic advance indicated a scope for genetic improvement of grain yield through selection.

Table.1 Variability, Heritability and genetic advance for quantitative traits in rice

\begin{tabular}{|c|c|c|c|c|c|c|c|}
\hline Characters & Mean & Range & $\begin{array}{c}\text { Genetic } \\
\text { coefficient } \\
\text { of variation } \\
(\%)\end{array}$ & $\begin{array}{c}\text { Phenotypic } \\
\text { coefficient } \\
\text { of variation } \\
(\%)\end{array}$ & $\begin{array}{c}\text { Heri } \\
\text { tabil } \\
\text { ity } \\
(\%)\end{array}$ & $\begin{array}{c}\text { Genetic } \\
\text { advance } \\
(\%)\end{array}$ & $\begin{array}{c}\text { Genetic } \\
\text { advance as } \\
\text { percent } \\
\text { mean }\end{array}$ \\
\hline $\begin{array}{l}\text { Days to fifty } \\
\text { percent flowering }\end{array}$ & 114 & $77-120$ & 1.86 & 16.86 & 0.94 & 0.50 & 0.43 \\
\hline Plant height (cm) & 71.06 & $55-92$ & 5.42 & 22.2 & 0.60 & 1.93 & 2.73 \\
\hline Panicles per $\mathbf{m}^{2}$ & 368 & $92-452$ & 38.5 & 26.45 & 6.04 & 0.81 & 0.22 \\
\hline Yield kg/ha & 4522.57 & $\begin{array}{l}2563- \\
6525\end{array}$ & 763016.7 & 3048722.0 & 0.65 & 900.2 & 19.90 \\
\hline
\end{tabular}

\section{References}

Hooker J. D., (1979) The flora of British India. Vol 2. Reeve L \& Co., Kent, England, Pp: 25.

Brar D. S., Khush G. S., (2003) Utilization of wild species of genus Oryzae in rice improvement. In: J S Nanda, Sharma SD Monograph on Genus Oryzae Pp. 283-309.

Singh S. K., Bhati P. K., Sharma A, Sahu V (2015) Super hybrid rice in China and India: current status and future prospects. Int. J. Agric. Biol. 17: 221- 
232.1. Genetic variability and association analysis in rice. Int. $J$. Appl. Biol. Pharm. Technol. 5(2): 6365.

Johnson, H.W. Robinson, H.F. and Costock, R.E., Estimates of genetic and environmental variability in Soyabean. Agronomy J., 47(7): 314-318 (1955).

Roy, B. Hossain, M. and Hossain, F., Genetic variability in yield components of rice (Oryza sativa L.). Environment and Ecology.19(1): 186-189 (2001).

Siva Subramanian, S. and Madhavamenon, P., Combining ability in rice. Madras Agricultural Journal. 60: 419-421 (1973)
Thirumala Rao, V. Chandra Mohan, Y. Bhadru, D. Bharathi, D. and Venkanna,. V. (2014). "Genetic variability and association analysis in rice", Int. J. Appl. Biol. Pharmm Technol., vol. 5, no. 2, pp. 63-65.

Venkanna, V., Lingaiah, N., Raju, Ch and Rao, V.T., Genetic studies for quality traits of $\mathrm{F}$ population of rice (Oryza sativa L.). Int. J. Appl. Biol. Pharm. Technol. 5(2): 125-127 (2014).

Vaithiyalingan, M. and Nadarajan, N., Genetic variability, heritability and genetic advance in $F_{1}$ population of inter subspecific crosses of rice. Crop Res., 31(3): 476-477 (2006)

\section{How to cite this article:}

Manjunatha, B., B. Niranjanja kumara, A.M. Maruthesha and Sannathimmappa, H.G. 2019. Quantitative Traits Analysis in Rice (Oryza sativa L.) Genotypes. Int.J.Curr.Microbiol.App.Sci. 8(11): 2581-2584. doi: https://doi.org/10.20546/ijcmas.2019.811.298 